\title{
Use of expiratory CT images in the diagnosis and localisation of airway complications following lung transplantation
}

\author{
Nikolay Bogush, ${ }^{1}$ Michael Eberlein, ${ }^{2}$ Pablo G Sanchez, ${ }^{3}$ Robert M Reed ${ }^{4}$
}

'University of Maryland, Baltimore, Maryland, USA ${ }^{2}$ Departments of Pulmonary and Critical Care Medicine, University of lowa, lowa City, Iowa, USA

${ }^{3}$ Department of Surgery, University of Maryland, Baltimore, Maryland, USA ${ }^{4}$ Departments of Pulmonary and Critical Care Medicine, University of Maryland, Baltimore, Maryland, USA

\section{Correspondence to} Dr Robert Michael Reed, rreed@medicine.umaryland.edu

Accepted 3 June 2015

\section{CrossMark}

\section{To cite: Bogush N,} Eberlein M, Sanchez PG, et al. BMJ Case Rep Published online: [please include Day Month Year] doi:10.1136/bcr-2015210694

\section{DESCRIPTION}

A 78-year-old man presented with dyspnoea and subacute decline in lung function several years after undergoing a left lung transplant for pulmonary fibrosis. He had a history of left anastomotic stenosis that had been treated for some time with a stent. Initially unclear whether his decline was associated with a recurrent anastomotic issue or whether he had developed another problem, such as chronic rejection (bronchiolitis obliterans), a CT scan of the chest was performed and showed a clear left lung on inspiratory views (figure 1 and video 1). Expiratory views, however, demonstrated normal emptying (uniformly increased attenuation) of the left lower lobe and lingula, but marked air trapping (persistently decreased attenuation) in the apical, anterior, and posterior segments of the left upper lobe (figure 1 and video 1), consistent with a diagnosis of anastomotic malacia resulting in significantly impaired ventilation.

This novel case demonstrates that CT images with expiratory views can help localise areas of obstruction as well as to differentiate between processes involving the large versus small airways. While many conditions involve a combination of large and small airways disease, the lung transplant population is distinct in that large airway (anastomotic) or small airway (bronchiolar) complications may occur in isolation of each other; therefore, the inclusion of expiratory views on a CT scan is of

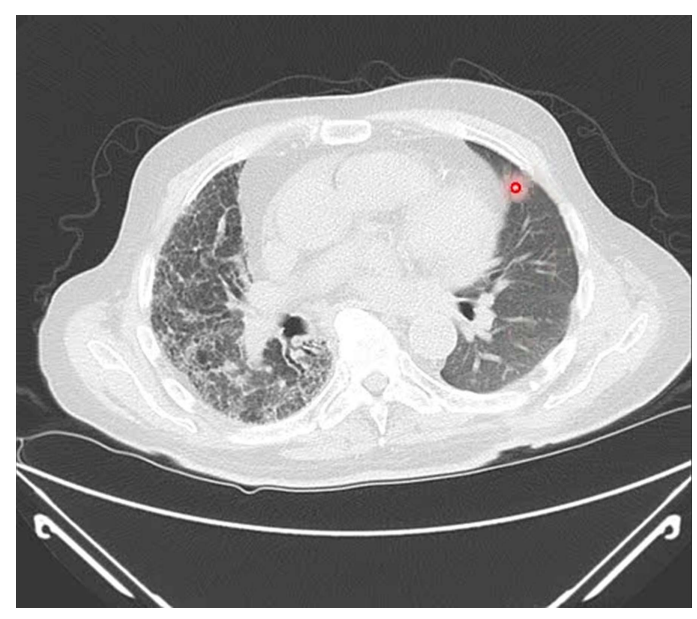

Video 1 Narrated review of the inspiratory and expiratory CT scans.

particular value in diagnosing and differentiating between these conditions. In bronchiolitis obliterans, expiratory obstruction appears patchy with scattered mosaic air trapping. ${ }^{1}$ Air trapping confined to certain lobes of the lung without a diffuse nature, as in this case is indicative of an anastomotic complication. This serves as a reminder of the value of expiratory views on a CT scan in the setting of a lung transplantation.

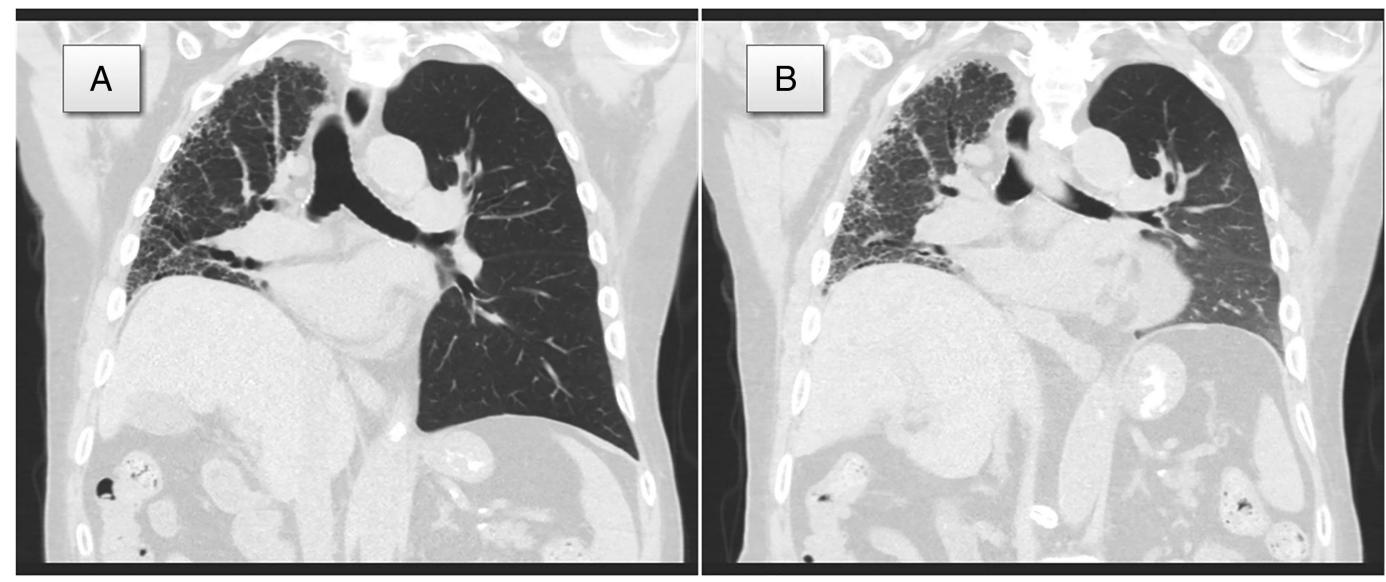

Figure 1 (A) Inspiratory CT of the chest. Coronal image demonstrates left lung without any infiltrates. (B) Expiratory CT of the chest. Coronal image demonstrates increased attenuation of the left lower lobe with unchanged attenuation within the left upper lobe consistent with segmental air trapping. 


\section{Learning points}

- Anastomotic airway complications occur in approximately $7-14 \%$ of patients within 1 year of transplant. ${ }^{2}$

- Expiratory CT views can help to differentiate between distal airways obstruction (example: bronchiolitis obliterans) and proximal airways obstruction (example: anastomotic stenosis or malacia).

- Expiratory CT views can help identify air trapping prior to measurable differences being detected through pulmonary function testings. ${ }^{3}$
Competing interests None declared.

\section{Patient consent Obtained.}

Provenance and peer review Not commissioned; externally peer reviewed.

\section{REFERENCES}

1 Gaeta M, Minutoli F, Girbino G, et al. Expiratory CT scan in patients with normal inspiratory CT scan: a finding of obliterative bronchiolitis and other causes of bronchiolar obstruction. Multidiscip Respir Med 2013:8:44.

2 Machuzak M, Santacruz JF, Gildea T, et al. Airway complications after lung transplantation. Thorac Surg Clin 2015;25:55-75.

3 Tanaka N, Matsumoto T, Miura G, et al. Air trapping at CT: high prevalence in asymptomatic subjects with normal pulmonary function. Radiology 2003;227:776-85.

Copyright 2015 BMJ Publishing Group. All rights reserved. For permission to reuse any of this content visit http://group.bmj.com/group/rights-licensing/permissions.

BMJ Case Report Fellows may re-use this article for personal use and teaching without any further permission.

Become a Fellow of BMJ Case Reports today and you can:

- Submit as many cases as you like

- Enjoy fast sympathetic peer review and rapid publication of accepted articles

- Access all the published articles

- Re-use any of the published material for personal use and teaching without further permission

For information on Institutional Fellowships contact consortiasales@bmjgroup.com

Visit casereports.bmj.com for more articles like this and to become a Fellow 